\title{
IMPACT OF THE SOCIAL ENVIRONMENT ON THE UPCOMING PROCESS IN THE LIGHT OF F. ZNANIECKI'S CONCEPT
}

\author{
Daniel Kukla \\ Mirosław Mielczarek
}

\begin{abstract}
The aim of the discussion is to analyse Florian Znaniecki's "Sociology of Education". The indicated author is an outstanding Polish sociologist originating from the Poznan scientific community. He gained international fame by work Polish Peasant in Europe and America, co-authored by William Thomas. In "Sociology of Education" the educational process was described and analysed from a sociological perspective. On the other hand, in this article, the authors propose to pay attention to other social factors in the $21^{\text {st }}$ century, which Znaniecki did not consider due to the period in which he lived. The thesis chosen for the presented work assumes that the issue of education is related to the field of science, which is sociology. The conclusions emphasize that such a relationship inclines to broaden knowledge in the field of sociology in the pedagogical environment and to use its achievements in educational work.
\end{abstract}

\section{Keywords}

sociology, upbringing, sociology of education, sociology of upbringing

\section{Introduction}

Education can be considered a universal human activity. It is a process which task is to introduce successive generations to the social community. Education is usually considered in a narrow sense, as an intentional and conscious educational impact, broadly encompassing all impacts shaping the individual as a person, his aspirations, preferences, system of values, attitudes and way of functioning (Katra, 2014, p. 105). It is also consciously organised social activity, based on the educational relationship between the educators and the pupil, the purpose of which is to cause the intended changes in pupils' personality (Okoń, 2001, p. 445). The changes taking place in 
the process of educating include both, the cognitive-instrumental and emotionalmotivational sphere (Zarzecki, 2012, p. 12). The cognitive and instrumental sphere is related to the ability to influence it and to learn about reality through social contacts. On the contrary, the emotional and motivational sphere determines the formation of the relationship of the individual to the surrounding people and the world (Lusek, 2013, p. 203-204).

From a scientific point of view, various fields deal with education. Pedagogy, sociology and psychology should be considered as the main ones. Pedagogy mainly focuses on the formulation of educational goals and the activities of educators to achieve them (Lusek, 2013, p. 203-204). Sociology in the context of education "examines how and to what extent social, economic and ecological structures and processes shape human personality" (Miczyńska-Kowalska, 2012, p. 13). Psychology, on the other hand, analyses and examines the psychological processes that occur in the education process. Its task is to understand the fact that under the influence of specific educational activities a person changes throughout his life (Grusec \& Hastings, 2008).

Educating and upbringing is a social process. It results, among others, from the fact that its primary goal is to educate the individual to function in society. Expanding knowledge about education as a social construct goes beyond pedagogy. Therefore, scientific research around the education process should be interdisciplinary. When analysing educational processes, it is worth basing on the achievements of other scientific fields, including, in addition to pedagogy, indicated sociology and psychology. This study focuses on linking the educational process with sociological knowledge. A special relationship between pedagogy and sociology occurs in the case of social pedagogy, in which sociology fulfils an extremely important source of knowledge, inspiration and provides research methods. An important period binding both areas was above all the $19^{\text {th }}$ and $20^{\text {th }}$ centuries. At that time, two trends, "pedagogical sociology" and "pedagogical sociologism" arose, where it was assumed that education depends above all on social conditions, which fundamentally differ from natural reality (Literski, 2015). Complementarity of both sciences gave rise to a coherent scientific discipline which is the sociology of education. Today, this department of sociology draws on the scientific achievements created in its area over many years. The variety of concepts, approaches, currents and thoughts incline to consider the process of education from several levels (Choczyński, 2011, p. 95). The essence of sociology of education is the study of social relations occurring during the process of upbringing and education (Okoń, 2001, p. 360). The term "sociology of education" also functions in common utility. In Poland, on the other hand, the concept apparatus 'education sociology' is more often used, whose main precursor was the outstanding sociologist from Poznań, Florian Znaniecki, creating its foundations in the first decades of the $20^{\text {th }}$ century (Karkowska, 2007, p. 12-14). His scientific achievements, insights, comments and experience in this field have achieved international status (Woś, 2016, p. 66). 


\section{The components of social environment affecting education}

Znaniecki believed that education should be related to the social process as a result of which it does not take place only between the student and the teacher. That is why it is reasonable to realise that a given pupil lives in a society that constantly affects him (Znaniecki, 1973, p. 3-37). In this case, the impact of the family environment, neighbourhood, peer groups, teachers and school should be considered.

Indirect education factors, such as theatre, books and cinema are also important (Znaniecki, 1973, p. 162). In the $21^{\text {st }}$ century, it is also justified to point to the computer and the Internet as those factors significantly translate into the education of the individual. However, Znaniecki, considering the period in which he lived, for obvious reasons, did not mention them.

The first and most important component of social environment is the family. It is considered the basic social cell constituting the foundation of education (Okon, 2001, p. 337). As Znaniecki wrote over 80 years ago, its role in this respect has generally weakened. Parental responsibilities were levelled, and this essentially translated into the educational process. With time, duties of a family began to be reduced only to provide childcare in the early stages of his life, which the mother usually does. Already in the $80 \mathrm{~s}$ of the twentieth century, a gradual transfer of the obligation to provide education to institutions, including schools, was observed. Znaniecki pointed out that wherever there is marital and parental love as well as favourable socio-economic conditions, the family's upbringing function can be fully realised (Znaniecki, 1973, p. 97-123).

Despite the passage of time, today there are also parents who commonly neglect or completely ignore the educational function of the family, which often translates into placing the child in a care and educational or resocialisation institution. In their actions, such parents usually focus on the child's physical aspects, thus forgetting that the child's upbringing should also take into account the mental sphere, because the educational process is a complex process and should be conducted in such a way. To prevent such situation, the quoted sociologist proposed a real pedagogization of society, including the family. Such activities should be implemented in workplaces, cultural centres and wherever there is a proclaimed need for parents to perform educational functions (Znaniecki, 1973, p. 97-123).

The next social factor on which education depends is the neighbourhood environment. This term should refer to a group of people living near a given unit with whom it interacts with society. The form of these contacts basically goes from one phase called direct to another of indirect nature. When writing about indirect contact Znaniecki meant telephone contact, but in the $21^{\text {st }}$ century one should first of all, point to the Internet as the basic form of indirect interaction. As a result of such technological progress, the neighbourhood environment has significantly weakened. Education has its basis also in imitation. The young person begins to observe all types of norms, values and behaviours displayed by their immediate surroundings and, based on the indicated imitation, begins to manifest them. Znaniecki emphasised that in this case there is a tendency to imitate, above all, negative traits without positive ones. 
Neighbourhood can have both a positive and negative impact on the upbringing of a young person. The way it happens depends primarily on the closest social group with which the person interacts (Znaniecki, 1973, p. 124-142). Today, the role of the neighbourhood environment has disappeared. This is especially visible in large cities, especially in the so-called concrete settlements, in which even the closest neighbour is often not known to the person. Despite this, there are situations in which neighbourly living negatively affects education.

Another factor, or rather factors conditioning education is the teacher, as well as the school. This work treats both factors as complementary ones, but Znaniecki described them separately. Turning to the role of a teacher in raising an individual, it can be stated that this process should be accompanied by mutual reflection. According to this assumption, the teacher should think about the goal he wants to achieve with the student and what methods he will pursue. The student should, however, have a reflection on the need and necessity of learning. In a situation where the student is not aware of these two basic things, the role of the teacher is to highlight such a need and necessity. Thus, the correct effects of not only learning but also upbringing can be achieved through properly selected educational contact.

Analysing the role of the teacher, it has been noticed that much better educational results are achieved by teachers who are characterized by kindness, a friendly attitude towards the student and consistent behaviour. In the case of those teachers who are characterized by good methodological and theoretical preparation, and who are not kind, consistent and friendly to the student, educational effects will be negligible. In his publication Znaniecki somehow "warned" that the use of all types of forms of coercion, punishment and excessive requirements is not conducive to the formation of an appropriate educational relationship. Thus, such activities do not lead to satisfactory results both in teaching and upbringing (Znaniecki, 1973, p. 162-175; 2011, p. 4958). As Szymański (2013, p. 124) noted, the school, like the family, is undoubtedly an institution influencing and educating. As a result, it is increasingly blamed for various types of problems and educational failures related to children and youth. Although the education and care of children falls under both school and family responsibilities, there are fundamental differences. One of the first views of Charles $\mathrm{H}$. Cooley is that a family is a natural group through its spontaneous creation that evolves over time. The school, on the other hand, is a kind of formal organisation, established to fulfil the tasks assumed from above. That is why family-oriented educational activities are usually natural and unaware. The school, on the other hand, should carry out the education process in full awareness and with responsibility, because it is regulated by educational rules and adopted canons.

Another factor that from a sociological point of view affects education is the peer group. Its role in this aspect, despite many years, has not been weakened as in the case of the neighbourhood. Peer groups are extremely important for proper development, including the education of young people. They basically affect the development of adaptation and communication skills of young people. Thanks to them a young man assimilates certain rules and norms of conduct that are not imposed in the form of orders and prohibitions 
universally binding in society but are those principles and norms that apply in a given peer group. An individual who is in such group learns cooperation and experiences fulfilling different social roles from those previously manifested. According to this, a child may be a leader dictating the conditions, and the other time someone who will have to comply (Szymański, 2013, p. 143-161, 176-199).

Analyzing Znaniecki's concept, one can only see the positive influence of the peer group on the upbringing process. Thus, it should be noted that there are groups that have a negative impact on young generations. In the $21^{\text {st }}$ century, we are increasingly encountering situations in which most peer groups begin to operate based on their own norms and principles that are in opposition to those acknowledged by most of the society. Belonging to a young person in this type of group adversely affects education process or can cause inhibition. What is important nowadays, most peer groups are identified with subcultures, which are quite often associated with gangs, crimes or sects. Such postmodern thinking encourages young people to become even more involved in a specific peer group to emphasise their diversity and independence. This disregards the rules and revolts against the values of most adults, which results in a faulty upbringing process.

The last social factor affecting education that distinguished Znaniecki is indirect education. The intermediate elements of upbringing include theatre, books and a cinema. However, it is also worth pointing to the computer, and more broadly to the internet, as an important (if not the most important at present) element affecting the education of children and young people. The characteristic feature of these factors is in this case not their direct impact, but as the name suggests indirect influence. In the case of films or books, their creators may consciously influence the education of the individual. That is why Znaniecki pointed out that not only direct contacts can shape the development, but also some kind of indirect elements that, through the message and then reception, shape a young person. Znaniecki noticed both the pros and cons of the influence of intermediate elements on the educational process. Negative aspects included the inflow of information, materials and forms of impacts for which a young person is not yet prepared, as a result of which many educational problems can occur. It is important that from many films and books one can also see those that will have a positive impact on the education of the individual through content appropriately selected for his age (Znaniecki, 2011, p. 200-210).

Nowadays, it is often observed the adverse impact of the growing number of mass media. Znaniecki did not raise this issue in his publication, because in his time this problem was not so visible. In the $21^{\text {st }}$ century, access to television, and what is characteristic, to the Internet, became widespread. However, it would be unreasonable to demonize all currently available media. On the one hand, they negatively affect a young person, on the other, they allow you to easily acquire knowledge and have faster access to information flow. However, the specific way the children and young people will use technology will depend primarily on parents, teachers and educators, because it should be inscribed in their upbringing process. 


\section{Conclusion}

To sum up, it should be noted that parents, neighbourhood, peer groups, teachers along with the school institution and elements of indirect education are not the only components of the educational environment. However, they are the most significant ones that affect the education of the individual (Znaniecki, 2000, p. 67). In pedagogical practice, it is worth emphasising the important knowledge of sociology that both, teachers and educators should exhibit in various types of care, resocialisation and educational institutions. Among the many tasks that are carried out in these centres, one of them is to lead and manage the upbringing process. Appropriate knowledge of social factors, which, as shown, have a significant impact on upbringing, will thus translate into educational success. Teachers, whether they want or not, are involved in a social "cobweb" relationship, which is inscribed in the school's institution. Therefore, this professional group as one of the few should use appropriate sociological knowledge. However, there are people who do not believe in the use of sociology in pedagogical practice. Thus, knowledge of the sociology of education can contribute to progress in teaching, as well as upbringing, because this is also the task of the school (Znaniecki, 2000, p. 317-318).

Components of the social environment play a fundamental role in the education process. Therefore, education both in families and in all types of facilities cannot be treated in isolation from sociology, and it should be skilfully used in pedagogical practice.

\section{References}

Choczyński, M. (2011). Wychowanie jako proces społeczny w teorii Floriana Znanieckiego. Uniwersyteckie Czasopismo Socjologiczne, 2011(6), 95-106.

Grusec, J. E., \& Hastings, P. D. (2008). Handbook of Socialization. Theory and Research. New York, London: The Guilford Press.

Karkowska, M. (2007). Socjologia wychowania. Łódź: Wydawnictwo Wyższej Szkoły Humanistyczno-Ekonomicznej.

Katra, G. (2014). Kulturowe i społeczne konteksty wychowania. Psychologia Wychowawcza, 2014(5), 105-114.

Literski, S. (2015). Pedagogika społeczna - tezy do wykładów. Retrieved November 20, 2019, from http://www.literscy.pl/stanl/pliki/tezy/3_1_3_2.pdf

Lusek, J. (2013). Wychowanie społeczne a wychowanie dla pamięci. Przegląd NaukowoMetodyczny. Edukacja dla Bezpieczeństwa, 2013(4), 203-213. 
Miczyńska-Kowalska, M. (2012). Socjalizacja w społeczeństwie ponowoczesnym. Lublin: Wydawnictwo Katolickiego Uniwersytetu Lubelskiego.

Okoń, W. (2001). Nowy słownik pedagogiczny. Warszawa: Wydawnictwo Akademickie "Żak".

Szymański, M. (2013). Socjologia edukacji. Kraków: Oficyna Wydawnicza "Impuls".

Woś, M. (2016). Czego może nauczyć młode pokolenia socjologów spuścizna po Florianie Znanieckim?. Edukacja Humanistyczna, 2016(2), 65-75.

Zarzecki, L. (2012). Teoretyczne podstawy wychowania. Teoria i praktyka w zarysie. Jelenia Góra: Karkonoska Państwowa Szkoła Wyższa.

Znaniecki, F. (1973). Socjologia wychowania, t. 1: Wychowujące społeczeństwo. Warszawa: PWN.

Znaniecki, F. (2000). Środowisko wychowawcze. Socjologia wychowania. Kielce: Wydawnictwo Stachurski.

Znaniecki, F. (2008). Metoda socjologii. Warszawa: Wydawnictwo Naukowe PWN.

Znaniecki, F. (2011). Relacje społeczne i role społeczne. Warszawa: Wydawnictwo Naukowe PWN.

\section{Authors}

prof. UJD, dr hab. Daniel Kukla, PhD.

Faculty of Social Sciences, Jan Dlugosz University in Czestochowa

ul. Waszyngtona 4/8, 42-200 Częstochowa, Poland

d.kukla@ajd.czest.pl

Mirosław Mielczarek

University of Lower Silesia

Department of Pedagogical Sciences

ul. Strzegomska 55, 53-611 Wrocław, Poland

mirek91.m@gmail.com 